\title{
Ethical Overview of Pharmaceutical Industry Policies in Turkey from Various Perspectives
}

\author{
Türkiye'de İlaç Sanayi Politikalarına Çeşitli Perspektiflerden Etik Bakış
}

\author{
Murat ORAL*, Gülbin ÖZÇELIKAY \\ Ankara University, Faculty of Pharmacy, Department of Pharmacy Management, Ankara, Turkey
}

\begin{abstract}
Objectives: Countries' national drug policies include all key stakeholders (pharmacists, physicians, pharmaceutical firms, and patients) in the public, the private sector, and the field of pharmacy. The aim of this study was to outline pharmaceutical patents and data protection, orphan drugs, drug pricing, and surplus goods regarding pharmacoeconomics, promotions, inspections in the pharmaceutical industry, and policies in pharmacies with respect to buying and selling drugs, and to discuss ethics in particular.

Materials and Methods: Written laws in force relating to drugs in Turkey constitute the materials of this study.

Results: Essential medicines must always be accessible. Both governments and pharmaceutical companies must fulfill the obligations imposed on them in an ethical way. Research and development activities must also be carried out for orphan drugs. While pricing drugs, authorities must take pharmacoeconomic evaluations into account.

Conclusion: Drugs must be accessible and in the first grade at all times under all circumstances because a product cannot replace it. The concept of surplus goods should be revised to ensure the common needs of the pharmaceutical industry, warehouses, and pharmacies. Promotions in the field by the pharmaceutical industry should be made based on scientific evidence in an ethical way. Inspectors should perform meticulous pharmaceutical industry inspections.
\end{abstract}

Key words: Drug pricing, ethics, health policies, patient rights, pharmaceutical industry, pharmacists

öz

Amaç: Ülkelerin ulusal ilaç politikaları kamu sektöründeki, özel sektördeki, eczacılık alanındaki tüm önemli paydaşları (eczacılar, hekimler, ilaç firmaları ve hastalar) içerir. Bu çalışmanın amacı Türkiye'de ilaçta patent ve veri korumasını, yetim ilaçları, farmakoekonomik açıdan ilaç fiyatlandırması ve mal fazlası kavramlarını, tanıtımları, ilaç sanayi denetimlerini ve eczanelerde ilaç alış ve satış politikalarını eczacı, ilaç firması ve hasta açısından ele almak ve özellikle etik açıdan tartışmaktır.

Gereç ve Yöntemler: Bu çalışmanın gereçlerini Türkiye'de ilaçla ilgili yürürlükte bulunan yazılı hukuk kuralları oluşturmaktadır.

Bulgular: Temel ilaçlar her zaman ulaşılabilir olmalıdır. Ilaç firmaları da devletler de kendilerine düşen yükümlülükleri etik olarak yerine getirmelidirler. Yetim ilaçlar için de Ar-Ge faaliyetleri yürütülmelidir. İlaçların fiyatları belirlenirken yetkililer farmakoekonomik değerlendirmeleri dikkate almalıdır. Sonuç: İlaç ikamesi olmayan bir ürün olduğu için her zaman her koşulda ulaşılabilmeli ve birinci kalitede olmalıdır. Mal fazlası kavramı ilaç sanayisinin, ecza depolarının ve eczanelerin intiyaçlarını ortak paydada sağlayacak şekilde yeniden düzenlenmelidir. İlaç sanayisinde tanıımlar bilimsel kanıtlara dayalı ve etik bir şekilde yapılmalıdır. Denetçiler ilaç sanayi denetimlerini titizlikle gerçekleştirmelidir.

Anahtar kelimeler: İlaç fiyatlandırıması, etik, sağlık politikaları, hasta hakları, ilaç endüstrisi, eczacılar

\section{INTRODUCTION}

There are different opinions about drug the patent protection regime brought to drugs with the Trade-Related Aspects of Intellectual Property Rights (TRIPS) Agreement, which arranges intellectual property rights. At the center of the discussions there are two counter-arguments:
1- Medicines are unique products because research and development (R\&D) costs and regulatory approval costs are significant parts of the total production costs. In fact, after having a drug developed and approved by the regulator, the marginal cost of medicine production remains negligible. R\&D costs and regulatory approval costs are mostly funded by the companies

*Correspondence: E-mail: ecz.murat.oral@gmail.com, Phone: +90 5057023282 ORCID-ID: orcid.org/0000-0001-5001-8477

Received: 15.10.2016, Accepted: 09.02.2017

๑Turk J Pharm Sci, Published by Galenos Publishing House. 
that first develop the drugs. The approval costs for generic medicines are not insignificant; however, generic medicine manufacturers face lower costs than the original medicine manufacturers for the same medicines. If there is not any profit for a limited period, new drug developers cannot meet R\&D and regulatory agencies approval costs and incentives to develop new medicines will substantially reduce. Therefore, drug patent protection is particularly important regarding technical development.

2- Some non-governmental organizations (NGOs) are pursuing these concerns against the TRIPS Agreement and patent protection for drugs; their beleif is that the increased patent protection would increase the price of medicines. Additionally, the number of new essential medicines under patent protection would increase, but it would be difficult to reach these essential drugs in developing countries due to the high prices. Thus, at the point of access to essential medicines, the gap between developed and developing countries would increase. The NGOs think the enforcement of related World Trade Organization rules would have an adverse impact on local production capacities and generic, innovative, high-quality drug resources, on which developing countries are dependent, would disappear. ${ }^{2}$

\section{Patent types in the pharmaceutical industry}

Fundamentally, for drugs, there are product patents and process patents. Product patents are related to any new medical or veterinary-oriented molecule or with active substances derived from nature. Process patents are related to the methods used to produce the crystal form or derivatives of any product, or in the production and preparation of drugs. ${ }^{2}$ Beyond these patents, there are form patents, derivative patents, drug substance mixture patents, formulation patents, and indication patents. ${ }^{3}$

\section{Human rights and intellectual property rights}

Human rights are specific rights of people, whatever their nationality, place of living, sex, national or ethnic origin, color, religion, language or any other characteristic. ${ }^{4}$ Intellectual property rights allow the creators or owners of patents, trademarks, and copyrighted works to benefit from their work or investments for creation. These rights are set out in Article 27 of the Universal Declaration of Human Rights, which provides protection of secular and spiritual interests of the author/owner of scientific, literary or artistic production. 5,6

\section{Right to health and medical care as a human right}

Article 25 of the Universal Declaration of Human Rights and Article 35 of the Charter of Fundamental Rights of the European Union (UN) guarantee the right to health and medical care. Section 12 of the International Economic, Social, and Cultural Rights Agreement, Article 24 of the Convention on the Rights of the Child, Article 12 of the Agreement on the Elimination of All Forms of Discrimination Against Women also guarantee the right to health and medical care. ${ }^{5,7-10}$

UN Economic, Social and Cultural Rights Committee consider the right to health as a basic right category, which can be divided into sub-headings of other specific categories. These classes are the control, prevention, and treatment of disease, and include access to essential drugs." According to The World Health Organization (WHO), 'essential medicines' are drugs that meet the needs of the majority of the population. These drugs must always be in appropriate amounts, and adequate doses with a price people and communities can afford..$^{12}$

\section{Situation in poor countries, global-scale problem}

Public institutions, especially of developing countries, are faced with a lack of financial resources, which is why they encounter difficulties regarding delivering high-price drugs as preventative or curative medicines to citizens due to patent protection, particularly to disadvantaged individuals and groups. Both at the national and international level, this scenario leads to great social injustice. As a result, these problems are increasing the ethical obligations of the pharmaceutical companies..$^{13}$

\section{Drug-research and development orientation}

Data of the report prepared by the United Nations High Commissioner of the WHO revealed that the pharmaceutical industry channels their studies first and foremost to 'profitable diseases', those that probably have the highest return in the market. Diseases such as tuberculosis or malaria, which affect people living in developing countries, are classified as bad investments and ignored. There is drug R\&D orientation according to disease type, and three types of diseases are mentioned ${ }^{14}$ :

1. First-type diseases, such as hepatitis B, affect many people in both rich and developing countries.

2. Second-type diseases are neglected diseases such as HIV/AIDS and tuberculosis, both poor and rich countries are affected, but they are more common in developing countries. ${ }^{15}$

3. Third-type diseases are also known as over neglected diseases such as river blindness and sleeping sickness, which affect more than one billion people and are seen widely in citizens of developing countries.

\section{Rare diseases-orphan drugs}

The United States of America (USA) defines rare diseases as diseases and conditions that affect fewer than 100.000 people. The European Union (EU) defines rare diseases as diseases that affect no more than 5 in 10.000 people, that threaten life, and chronically debilitate the body. ${ }^{16}$ To date, there are 5000 8000 known rare diseases. Thirty million Americans and 3040 million Europeans are affected by these diseases. Although 250 new rare diseases are discovered each year, there are acceptable treatments only for 200-300 of rare diseases.

\section{Drug pricing and surplus drugs}

Nowadays, health needs are steadily increasing, and at the same time, there is a continuous improvement in technology. Those in decision-making positions in health economics are facing problems related to providing more health services, because of scarce resources, and financing those services due to the increasing trend in health needs and improvements in technology. Hence, decision-makers benefit from health economics and pharmacoeconomics, which is a sub-discipline of health economics regarding the effective and efficient use of available scarce resources. 
Pharmacoeconomics has emerged as a sub-branch of health economics. Pharmacoeconomics compares different pharmaceutical products from the same therapeutic class through the consideration of cost-benefit, cost-utility, costminimization, and cost-effectiveness analyses or compares a treatment method with surgical alternatives. It is even used to demonstrate the benefits of the establishment of some pharmaceutical services or to compare these services with themselves. Table 1 shows cost units and result units. At decision-making stages during pharmacoeconomic analyses, decision-makers evaluate expenses and results. Costs in pharmacoeconomics are direct costs, indirect costs, and intangible costs. Direct costs express drug expenditures, medical examination fees, laboratory tests, diagnostic transaction costs, and the money directly paid by patients and relatives of patients for treatment. Indirect costs are factors such as reduction of a patient's ability to work or early death. Intangible costs are factors such as stress and pain, which are difficult to calculate in monetary terms. Regarding pharmacoeconomics, evaluators take direct costs into account and make assessments.

Due to the day-by-day increase in the need for healthcare and scarce resources available around the world, the presence of various regulations on drug pricing emerges as a necessity. In Turkey, there is a Reference Pricing System (RPS), which is a common worldwide practice used for drug pricing.

Surplus goods are 'pharmacists chance to earn money,' 'pharmacist savior campaigns made by pharmaceutical warehouses,' 'the same kinds of goods supplied free-of-charge next to purchased goods; but what truth is there in these statements? Surplus drugs are goods given toll-free by drug companies to pharmacies via distribution channels, and at the same time, they are quantity discount practices. ${ }^{17}$ In the process of the supplier's sales, surplus goods are motivational tools to increase sales volumes; however, regarding the receivers, surplus goods mean stock loading. All around the world, the pharmaceutical sector uses surplus goods. For instance, consider a campaign: if the pharmacist buys ten pieces of drug $A$ into his pharmacy, the surplus goods will also be ten [drug $A$ 10 (purchased) +10 (free of charge)]

\section{Promotions and inspections in the pharmaceutical sector}

Drug promotions cover the activities of license/permit holder companies to provide information for health professionals. In Turkey, as in the entire world, drug promotions must be made in compliance with the various procedures and principles within the framework of ethical principles.
The inspection function is the last role of the management functions and located in the corresponding position. The inspection of pharmaceutical manufacturing plants is highly critical for everyone.

\section{Ethics}

Ethics is a synonym of moral philosophy, which is a branch of philosophy. In this discipline, researchers try to determine which practices are good or bad, right or wrong, virtuous or immoral, fair or criminal. While making these assessments, ethics benefit from ethical principles such as respect for autonomy, justice, beneficence, non-maleficence, accuracy, and privacy. Thus, ethical principles are relevant for the evaluation of pharmaceutical industry policies.

\section{EXPERIMENTAL}

Written laws in force relating to drugs in Turkey constitute the material of this study. Legislations as accessible through the e-legislation website of The Republic of Turkey Prime Ministry General Directorate of Legislative Development and Publication Regulatory Information System including current changes, were used as references for this study. Legislations related with our study are: Industrial Property Law (The Official Gazette of Republic of Turkey 10.01.2017; 29944), Licensing Regulation of Human Medicinal Products (The Official Gazette of Republic of Turkey 19.01.2005; 25705), Communique on the Pricing of Human Medicinal Products (The Official Gazette of Republic of Turkey 11.12.2015; 29559), Regulation on Promotional Activities of the Human Medicinal Products (The Official Gazette of Republic of Turkey 03.07.2015; 29405), Regulation on Manufacturing of the Human Medicinal Products (The Official Gazette of Republic of Turkey 27.04.2013; 28630), Turkish Medicines and Medical Devices Agency Regulation of Health Auditors (The Official Gazette of Republic of Turkey 30.05.2013; 28662). Especially legal rules related to patents, orphan drug practices, access to drugs, pricing, promotion, and inspections will be discussed and assessed regarding pharmaceutical companies, pharmacists, and patients.

\section{RESULTS}

\section{Drug patents}

In Turkey, there is Industrial Property Law. ${ }^{18}$ The protection provided to medical and veterinary pharmaceutical manufacturing processes and product patent certificates began on January 1, 1999. The use of magistral drugs is beyond the scope of patent rights. Information and test results, whose

Table 1. Basic pharmacoeconomic analysis methods, cost, and result units used in these methods

\begin{tabular}{lll} 
Pharmacoeconomic analysis method & Cost unit & Result unit \\
\hline Cost-benefit analysis & Money & Money \\
\hline Cost-utility analysis & Money & QALY and other utilities \\
\hline Cost-minimization analysis & Money & The comparison of equivalent group results \\
\hline Cost-effectiveness analysis & Money & Natural units (e.g., change in blood pressure, blood sugar, weight loss) \\
\hline QALY: Quality-adjusted Life Years & & \\
\hline
\end{tabular}


creation and accumulation requires a significant effort, expense and whose owners did not disclose to the public, are requested by the related authorities for certification of manufacturing and sales licenses of a patent application. Information on veterinary and agricultural drugs shall be kept confidential by the requesting authority. The authority requesting information and test results shall take the necessary measures to prevent their unlawful use. The duration of the patent given by examination is twenty years starting from the application date and cannot be extended. The duration of patents given without examination is seven years. If the review request is performed within seven years and at the end of this period if it is decided to award a patent, the patent duration will be integrated to twenty years starting from the application date. The patent owner or the authorized person must use the invention protected by patent. The obligation for use is within three years from the announcement of the patent award in critical bulletins. In the evaluation of use, market conditions are taken into consideration. Patents can be converted into compulsory licenses if patent-related inventions are not used and are subject to public interest. A compulsory license is a legal right granted by the Government without the permission of the patent holder to benefit from the patent. ${ }^{19}$

In Turkish law, the original drug's patent protection period should have ended for a generic drug to be licensed. Generic pharmaceutical companies that make drug applications do not have to present results of toxicologic and pharmacologic tests or clinical trials in the event that the generic drug is similar to the original drug and consent has been obtained from the original pharmaceutical company having a licence in Turkey. ${ }^{20}$

However, for topics related to public health, license applications for generic medicines can be accepted concerning the data of the original drug by making an exception to the original drug data exclusivity without making additional studies. The Council of Ministers of the Republic of Turkey may decide upon patent applications or the inventions subject to patents as compulsory license issues when they are useful to the public. Regarding the interest of public health or national defense of putting an invention into practice; if there would be an increase in the use of the invention or dissemination in general or reforming for a beneficial use is of great importance, it is accepted that there is the public interest. ${ }^{21,22}$

\section{Drug pricing and surplus drugs}

In Turkey, RPS is used for drug pricing. Moreover, drug pricing activities are carried out according to the Communique on the Pricing of Pharmaceuticals for Human Use. There are five reference countries for drug pricing in Turkey: Spain, France, Portugal, Greece, and Italy. Every year, a constant Euro / Turkish Lira (TL) exchange rate is determined; for instance, 1 Euro=2.3421 TL). By using RPS, the lowest prices of the drug found in reference countries are taken into account while calculating the price of the drug. When the mentioned condition is evaluated in a pharmacoeconomic analysis, it is understood that cost-minimization analyses are directly or indirectly carried out. While applying the RPS, the Euro value is determined by multiplying the average annual value of the
Euro (annual average daily selling Euro exchange rates of the Central Bank of Turkey and as declared in the Official Gazette of the Republic of Turkey) with the adaptation factor, which is determined as $70 \%$. When pricing medicinal products for the first time, if the ex-factory price is below $3.63 \mathrm{TL}$, reference price monitoring is not made. ${ }^{23}$

Pricing of Original Products: If the original product enters the market for the first time (regarding active substance), its price must not exceed $100 \%$ of the lowest price of the reference product's price in reference countries.

Pricing of twenty-year products: The prices of twenty-year original products (regarding active substances), whose sale price to wholesalers is above $6.79 \mathrm{TL}$, may be a maximum $80 \%$ of the reference prices. At the first pricing of twenty-year products, if the selling price to wholesalers is less than 6.79 TL, the selling price to wholesalers may be $100 \%$ of the reference price.

Pricing of generic products: The price cannot exceed $60 \%$ of the original product's reference price in Turkey. If the price of the original product is less than the reference price, for the pricing of the generic drug, $60 \%$ of the reference price is taken into account. Thus, if the price of the original product is less than the reference price due to commercial concerns (entering the reimbursement list, the emergence of small price differences at pharmacies), $60 \%$ of the reference product is considered for the pricing of the generic product. At the first pricing of the generic products, if the selling price to wholesalers is less than $3.56 \mathrm{TL}$, the selling price to wholesalers may be $100 \%$ of the reference price.

When the first generic of the original product enters the market, the reference price of the original product is reduced from $100 \%$ to $60 \%$. The price of the original product may be exactly $60 \%$ of the reference price or less due to commercial concerns of the owner company.

Pricing of combined drugs: for example, the related drug consists of 20 tablets, each of which contains $100 \mathrm{mg}$ paracetamol and $200 \mathrm{mg}$ atorvastatin as active drug substances. The basic principle for combined drugs: if two or more drug substances unite and form quite another indication, different from their indications alone, in that case, this combined drug is evaluated as an original product. Namely, if the combined drug consisting of analgesic and antihyperlipidemic drug substances is antineoplastic or antiviral, and if this indication is proved scientifically, this combined drug is then assessed as an original drug. However, these kinds of drugs are very few, which is why almost all combined drugs are evaluated as generic medicines.

Primarily, it is checked as to whether there is an identical combined drug (namely, a combined drug consisting of 20 tablets, each of which containing $100 \mathrm{mg}$ paracetamol and $200 \mathrm{mg}$ atorvastatin) on the Turkish market. If there is such a combined drug available in Turkey, then the price of the 'new' combined drug cannot exceed the price of that already on the market. If there is no equivalent combined drug on the Turkish market, then the five reference countries are checked 
for the probability of finding a like-for-like equivalent original combined drug. If there is no equivalent combined drug in the reference countries, the Turkish market is verified for combined drugs that can be scaled from small-packaged in nature, or small doses (e.g., combined drug consisting of 10 tablets, each containing $50 \mathrm{mg}$ paracetamol and $100 \mathrm{mg}$ atorvastatin). If there is no combined drug that can be scaled in Turkey, the market is then checked for combined drugs that can be scaled from a large-packaged nature or large doses (e.g., 40 tablets, each containing $200 \mathrm{mg}$ paracetamol and $400 \mathrm{mg}$ atorvastatin). The process for pricing is always the same. In essence, a likefor-like equivalent is searched for, if there is no equivalent, then the nearest small equivalent is investigated. If there is no nearest small equivalent, then the nearest large equivalent drug is searched for, and finally, price rationing is made. Related to the pricing of combined drugs, if there is no reference combined drug in Turkey (if there are neither small- nor largeform like-for-like equivalent drugs), then original products sold separately in the same doses are sought. That is, the market is searched for original drugs containing $100 \mathrm{mg}$ paracetamol and another drug containing $200 \mathrm{mg}$ atorvastatin. If there are original medicinal products on the market, first, a like-for-like equivalent is searched for; if there are no equivalent drugs in the market, then the nearest low- and high-dose equivalents medicines and the nearest single equivalent drugs are sought, respectively. Finally, rationing is made for drug pricing by calculating $60 \%$ of the reference drug's price because the combined drug is accepted as a generic drug. If there are no original drugs containing drug substances (paracetamol and atorvastatin) of the combined drug, then the highest-priced generic products in Turkey are taken into account.

\section{Surplus goods from the perspectives of the pharmaceutical industry}

The pharmaceutical industry uses surplus goods as tools to increase sales volume in a highly competitive environment, promoting the products on the market, thus transferring the stock cost and risk to the post-production pharmaceutical supply chain (pharmaceutical warehouses, distribution channels, and pharmacies).

\section{Surplus goods from the perspectives of the drug distribution channels}

Distribution channels are interfaces between the pharmaceutical industry and pharmacies. Distribution channels think that surplus goods are marketing policy tools of the pharmaceutical industry, tools for increasing sales volumes, and a way sharing stock costs and risks with pharmacies, which are last in pharmaceutical supply chains. The direct and indirect benefits of drug distribution channels from surplus goods are dependent on parallel actions compatible with pharmacies and a "win-win" policy because if the selling of surplus goods to pharmacies from distribution channels is not healthy and measurable, problems linked with post mature products, stock cost, and the inability of drug prescriptions returns as a load on distribution channels.

\section{Surplus goods from the perspectives of pharmacists}

Although surplus goods from the perspectives of pharmacists are quantity discount practices that reduce unit cost purchasing and increase the gains on sales, they are factors in pharmacies that increase stock holding costs and stock carrying risks, such as decreased prices, post-mature problems, wastage, and chames in public institution's discount (the discount given by pharmaceutical companies to the Government for products within the scope of reimbursement, billed to the Social Security Institution); additionally, they affect cash flow. The frequent replacement of prescribed drugs by doctors as a result of unethical practices by the pharmaceutical industry reveals risks and costs related with surplus goods for pharmacists. In addition, unfortunately, the selling strategies and planning of industry and distribution channels are not available in pharmacies. For instance, while the reimbursement agency is paying the invoice amounts of drugs to pharmacists at an average of 60 days, if the pharmacists do not evaluate the conditions of purchasing goods with surplus goods correctly, then there is no profit for those goods; on the contrary, pharmacists will have to bear the stock costs of the goods as surplus goods.

The conditions of pharmaceutical warehouses regarding surplus property and regarding commercial discounts (discounts given by drug companies to pharmacies for making their products more attractive) are significant for pharmacists. This discount is reflected in pharmacies by bypassing warehouses. Nowadays, the number of drug companies providing trade discounts has decreased greatly. Additionally, warehouse deal discounts (additional discounts reflected by warehouses to pharmacies as a result of commercial treaties) tend to decrease.

Regarding tax legislations, because surplus goods increase profit margins by reducing costs, they attract extra attention from tax authorities. There are many problems between tax authorities and pharmacies because there are inadequate facilities for accounting; if surplus goods are not handled in accounting books, then surplus goods are considered as cash sales, and pharmacies are subject to criminal procedures regarding income taxes and value-added taxes. ${ }^{24}$

\section{Surplus goods from the perspectives of patients}

Pharmacists purchase goods according to the socio-economic, socio-cultural, and educational levels of the people living in their neighborhoods. For example, in a neighborhood where the social and economic level of people is high, people want the same drugs (mostly expensive original medicines) prescribed by the doctor. The reimbursement agency pays the price of the cheapest equivalent drug, and the patient pays the rest. In affluent areas, patients can pay the price difference easily because they have money. In addition, patients in these regions go to private doctors' offices and purchase the prescribed drugs by paying the full fee of the prescribed drugs. Pharmacists whose pharmacies are in these kinds of regions do not purchase many generic drugs because patients generally request the expensive original medicines. Surplus goods are given mostly with cheap generic drugs, accordingly, such pharmacists mostly do not purchase drugs with surplus goods because the 
patients can buy the drugs with cash and the selling rate of expensive cosmetic products is high. Also, cash flow at these pharmacies is very high. Cash flow is a crucial factor for trade, as such these pharmacists earn enough to compensate for the positives of purchasing drugs with surplus goods. In contrast, in places where people's socio-economic levels are low, people do not have enough money to buy original drugs. Thus, residents in these neighborhoods usually do not want to pay money at pharmacies, and they accept generic equivalent drugs, which are paid in full by the reimbursement agency. Also, people in these regions do not purchase expensive cosmetic products, and cash flow, which is critical for trade, is very low. Therefore, pharmacists whose pharmacies are in those regions usually purchase generic drugs with large amounts of surplus goods because they try to make up for the cash loss and try to gain through purchasing drugs.

\section{Rare diseases and orphan drugs}

There is a paucity of accessible data about the prevalence of rare diseases in Turkey, but researchers estimate that at least 5 million people have at least one rare disease. More importantly, millions of patients and their many relatives try to obtain a rapid diagnosis and effective treatment. ${ }^{21}$ Orphan drugs are medicinal products developed to treat rare diseases in humans. In Turkey, there is no regulation directly related to orphan drugs. ${ }^{22}$ On the Amendment of the Communique on the Pricing of Pharmaceuticals for Human Use ${ }^{23}$, orphan drugs are defined as drugs used for diseases with an incidence of less than $1 / 100.000$ people, and which are not exactly defined. The same communique expresses that orphan products can be priced up to the reference price put forth with official documents obtained from the country of import and manufacture, and the price of these commodities will be revised every year making calculations on sales amounts. In Turkey, according to the Regulation on the Licensing of Human Medicinal Products, the Ministry of Health finalizes full drug registration applications, whose preliminary investigation is completed within 210 days following the acceptance of this application by examining the fulfillment of regulatory requirements. In Turkey's drug regulations, the parts that can be associated with the orphan drugs are: registration of filed drugs being the first in the treatment or diagnosis of diseases; innovation or reduction of public spending on health; and requirement in terms of public health. Examination are completed after no more than 180 days to ensure rapid access to the whole community. Also in the same Regulation, it is stated that the authority can issue licenses depending on certain conditions such as rarely seen indications of the referring drug and accordingly, when the applicant cannot provide absolute evidence for efficacy and safety. ${ }^{20}$

The first diagram shows the percentage distribution of EU orphan drugs in Turkey. Twenty-eight percent of licensed EU orphan drugs are not available for use in Turkey. The second diagram is about the percentage distribution of licensed EU orphan medicinal products used with different access procedures in Turkey. Thirty percent of EU-licensed orphan drugs have also been licensed in Turkey; $70 \%$ of EU-licensed orphan drugs are used in Turkey through off-label use approval (Diagram 1, 2).

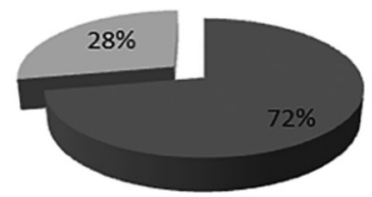

all the licensed EU orphan drugs Used in Turkey.

- Licensed EU orphan drugs not found in Turkey.

Diagram 1. Percentage of Licensed European Union Orphan Drugs in Turkey 22

EU: European Union

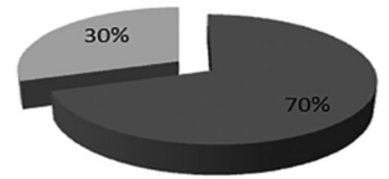
- Licensed EU orphan drugs used in Turkey by the off-label use approval
EU orphan drugs licensed in Turkey and EU

Diagram 2. Percentage of Licensed European Union Orphan Drugs used by different access procedures in Turkey ${ }^{22}$

EU: European Union

The above graph shows the therapeutic area distribution of the EU-licensed orphan medicinal products used in Turkey. The majority of orphan drugs used in Turkey are oncologyhematology drugs. There are twenty oncology-hematology orphan drugs, eleven for gastroenterology-metabolism, four for cardiology, two for endocrinology, one for infections, and two orphan medicinal products used for other therapeutic purposes (Graphic 1).

\section{The Therapeutic Area Distribution of the EU Licensed Orphan Drugs Used in Turkey}

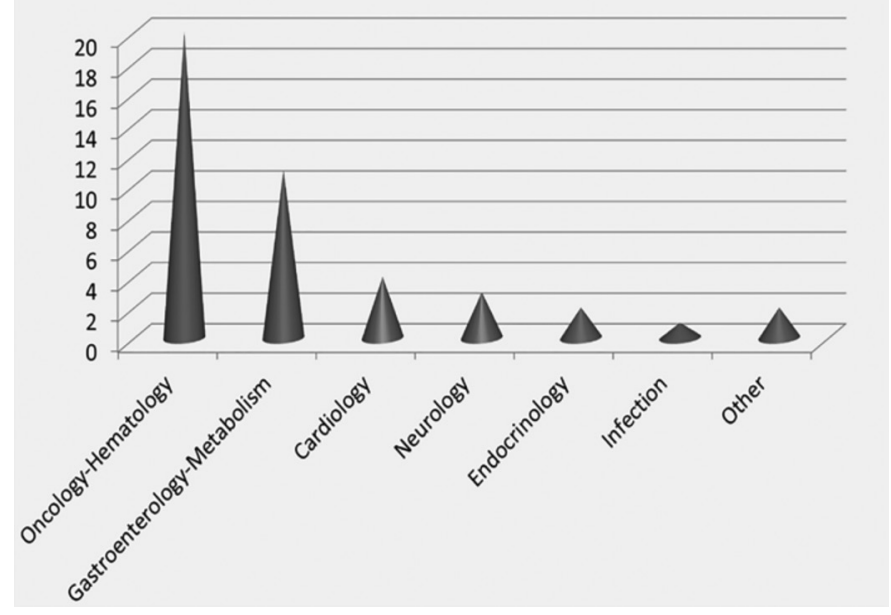

Graphic 1. The therapeutic area distribution of orphan drugs in Turkey in $2011^{22}$

EU: European Union 
Patients' access to orphan drugs in Turkey and ethical approach

In Turkey, people can access orphan drugs through licensed sales, even if not authorized in Turkey, by the procurement of approved orphan drugs from the USA and EU. Alternatively, orphan drugs can be accessed though case-by-case prescription approval of medicines whose efficacy and safety are verified with an ongoing clinical trial protocol, or by the clinical use of yet unapproved drugs on patients with severe diseases. In Turkey, regardless of their authorization status, all orphan medicinal products are covered with $100 \%$ reimbursement. ${ }^{16}$

\section{Drug promotion in the pharmaceutical industry}

Drug promotion in the Turkish pharmaceutical industry must be performed according to the Regulation on Promotional Activities of Human Medicinal Products as published by the Ministry of Health of Turkey, Turkish Medicines and Medical Devices Agency (TITCK). Promotion covers all the informing activities, all the promotional staff activities about the medicalscientific features of the medicinal products for human use within the scopes of the Regulation held by the owners of the licenses/permits for healthcare professionals, advertisements that are given to medical and professional books and journals, announcements made by direct mailings or through the press or other means of communication, scientific/educational activities, and meetings and other events held by the industry. Promotional materials include printed materials such as books, booklets, and brochures, containing sufficient and necessary information about the product; film and slides; audio /visual materials provided with storage devices such as flash memory drives and CD/DVDs; every kind of publication that may be used as information/data/reference; free samples; programs and materials for patient education; reminder visiting materials such as pens, pencils, notepads, and calendars whose monetary value should not exceed $2.5 \%$ of the current monthly minimum gross wage. Product promotional staff pertains to people who have received a certificate of qualification and who promote products to physicians, dentists, and pharmacists via direct visits. Qualification certificate refers to that given directly to university graduates of the medical promotion department and the marketing program by the Turkish Ministry of Health or the certificate provided by examination at the end of the in-service training approved by the Ministry. ${ }^{25}$

Healthcare professionals includes physicians, dentists, pharmacists, nurses, and midwives. Health professionals must declare all kinds of support given by the owners of the licenses/ permits when they write an article at the end of each article, when they talk or present something at the beginning of each speech/presentation. All scientific and educational activities relating to promotions of medicinal products for human use cannot be used, except to transfer existing medical information, and to present new information. The owners of the licenses/ permits cannot directly or indirectly cover transportation and accommodation costs of respondents participating in these activities. Meetings at which healthcare professionals attend must be related with their expertise/task fields. A healthcare provider can benefit from this support a total of three times in the same year; two of these three supports can be held by the same license/permit owner and only one can be used abroad. Meetings at which healthcare professionals attend as speakers or report research with the support of license/permit owners are not considered within this scope. ${ }^{25}$

\section{Pharmaceutical industry inspections}

Inspections of the pharmaceutical industry regarding Good Manufacturing Practices (GMP) are performed according to the Regulation on Manufacturing Sites of Medicinal Products for Human Use. ${ }^{26}$ TITCK inspects manufacturing plants that have manufacturing permission within a program by giving prior notice. In addition, the Agency can inspect manufacturing plants when necessary without further notification. Health inspectors are authorized to examine all documents related to manufacturing, quality control, and quality assurance, and also for sampling when needed, and examining other recordings. The matters required for notification are indicated in the inspection report, and the Agency announces these issues. The Agency may inspect the manufacturing plants of imported drugs. According to TITCK Regulation on Health Inspectors ${ }^{27}$, health inspectors have to graduate from faculties such as law, political information, economics, business, economics and administrative sciences, health sciences, medicine, dentistry, pharmacy, engineering, biology, and chemistry.

\section{DISCUSSION}

\section{Drug patents}

Drugs are defined as essential social products used for or foreseen to be used for changing physiologic systems or pathologic conditions to the benefit of users. At first glance, although drugs are not different from other inventions subject to patent rules, their use to protect people against diseases or to diagnose/improve a patient's condition determines its exchange value. Drugs cannot be replaced with any other product. Thus there is no direct relationship between the drug price and the patients' purchasing power. The demand for drugs is independent of its exchange value and the purchase request depending on this value. Direct interest in the medicine in the right to human health and life as a commodity or a product places needy drug consumers demanding the drug in a particular position and differentiates them from consumers in the classic sense. This situation makes a person socially powerless in the period up to access to drugs in the face them meeting a patient if they require protection against the patient. In the process for available drugs, patent owners, manufacturers, physicians, and pharmacists have several functions.

In the case of first-type diseases in promoting R\&D in the pharmaceutical industry, market mechanisms in wealthy countries, public funding for basic studies, and patent protections provide benefits. However, the level of technological and economic development of developing countries does not allow for the development of drugs and vaccines, thus patent protections and high prices represent an obstacle for the supply of current drugs. R\&D activities made for second-type diseases are shaped not by global needs, but mostly by the 
demands of rich countries' markets. When it comes to third category diseases, to which developing countries are exposed, the market mechanism that functions in affluent countries does not work. The TRIPS regime accelerated this deprivation.

\section{What can governments do?}

- When a new drug is invented, governments could give awards to the company rather than give a product patent, thus, because there will be no a related patent, generics of the new invented original drug may be launched to the market more easily.

- Compulsory License Agreements made by governments: with the results of government enforcement, the transfer of patent right without the inventor company's request may be performed rather than transferring with provision for material benefits to another company; therefore, generics of the new invented original drug may be put into the market easily.

- Parallel imports: the importation of a product from a country where the product is sold cheaper to another where the product is sold more expensively without the permission of the manufacturer or distributor may be conducted.

\section{"Respect" Liabilities of Pharmaceutical Companies Regarding Ethics ${ }^{14}$ :}

1. When creating missions, companies should enfranchise human rights in general, in particular the clear right to the highest attainable standard of health, and should avoid any behaviors that could lead to a violation of these fundamental rights.

2. Companies should respect the national laws of governments of countries in which they reside or operate.

3. Companies should avoid any behaviors that would encourage acting contrary to human rights norms, including the right to health born of the national or international laws of governments.

4. Companies should give an undertaking about not performing lobbying activities against the implementation of flexibility provisions including parallel imports and compulsory licensing relating to the TRIPS Agreement, and allowing access to drugs by governments in related countries with a request for the protection of intellectual property interests.

\section{"Realization" Liabilities of Pharmaceutical Companies Regarding Ethics ${ }^{14}$ : \\ 1. When companies formulate and apply their strategies, policies, programs, projects and activities, they should show a special effort for people and groups who are poverty-stricken and classified as disadvantaged, and also for women and children who face discrimination such that they benefit from the highest standards of health.}

\section{Companies should participate in the UN Global Compact.}

3. Companies should constitute a board-level system of governance that will take responsibility for their access to the drug strategy.

4. Companies must give a public undertaking about contributing to R\&D against neglected diseases and should consult with relevant civil society organizations. Companies should provide investigation and development studies against neglected diseases within themselves or should support outside companies and disclose studies related to these diseases.

5. Companies should make technology transfer agreements with local firms of low and middle-income countries.

6. When creating their price policies, companies should take into account the development level of the countries. They should have different drug pricing in low, medium, and highincome countries.

\section{Rare diseases - orphan drugs}

As mentioned earlier, pharmaceutical companies have mostly been conducting R\&D for profitable diseases. Therefore, orphan drugs always remain in the background. They exhibit approaches that do not comply with the right to health in the perspectives of ethics. Some questions must be asked: Is money everything? What about human health? What about the right to health?

In the clinical research process of orphan drugs yet to receive regulatory approval, the utmost importance should be given to ethical principles in the implementation of supply to people with severe illnesses. At this point, informed consent, respect for autonomy, beneficence, and harm to ethical principles are becoming crucial.

In Turkey, when pricing orphan drugs, 5\% more of the reference price may be given to these drugs by leaving pharmacoeconomic concerns aside, and thus we can easily conclude that rare diseases and orphan drugs are taken into account in Turkey. The right of access to orphan medicinal products is an essential right for all people of the world, regardless of differences regarding ethics. The Government must also do their utmost in this regard.

\section{Drug pricing and surplus drugs}

\section{Pricing of drugs}

At the time of this study, the Euro/TL exchange rate is (1 Euro= 4.030 TL). However, when pricing drugs, the Euro/TL exchange rate is fixed as (1 Euro= $2.3421 \mathrm{TL}$ ). The currency differences with the countries concerned should be arranged by taking available national resources into account, and there must not be any problem regarding the supply of essential drugs of foreign origin. Another point that can be debated is the quality of pharmaceutical substances. Drugs are essential products, and therefore should always be accessible in all circumstances and at first grade.

\section{The ethical impact of surplus goods among pharmacists}

Surplus goods given at a irrational levels create significant economic differences among pharmacies, and the differences are gradually increasing. The pharmacists' respect for manufacturer providing irregular surplus goods is gradually diminishing. Tax offices evaluate pharmacies as earning considerable amounts of money, and this sentiment creates moral corruption and unnecessary competition among pharmacists. Also, when we consider patients, for pharmacists to be ethically justified, they should pay attention to giving 
generic drugs, with which patients will be provided optimal benefit. Thus, pharmacists should distance themselves from financial matters when considering the health of the patient.

The optimal situation regarding surplus goods

Relating to the sustainability of commercial activities in pharmacies, the thing to be understood from products with surplus at a logical level is the supply of commercial discounts at rates of $4-7 \%$, in line with the payments of reimbursement institutions and with a maturity of at least 60 days.

\section{Promotion in the pharmaceutical industry}

In the Turkish pharmaceutical industry, promotions should not only be for profit purposes and should not be conducted by non-qualified people. Drug promotions should be made based on scientific evidence and in an ethical manner by qualified product promotion members. Healthcare professionals should demonstrate sensitivity to related issues, and they should not provide themselves unethical benefits and earnings as a result of unethical behaviors. Also, while making drug promotions, transferring pharmacoeconomic evaluations related to drugs to healthcare professionals is important to allow for assessment of the drug from a wider perspective.

\section{The pharmaceutical industry inspections}

Considerations for pharmaceutical industry inspections and the ethical approach

Pharmaceutical industry inspections should go beyond the scope of relevant legislation. Inspections should be carried out transparently by qualified inspectors on a scientific basis, and it should not be forgotten that humans will directly use the medicine manufactured in the inspected drug manufacturing facility. Inspections are crucial because the drugs must always be first grade. Inspectors should inspect all sites justly, and unethical practices should absolutely be avoided. Inspectors who perform GMP inspections must educate themselves at all levels about the process from the manufacturing of drugs until delivery to patients, regarding knowledge and skills, and they should comply with ethical principles. Inspectors should sign an ethical contract on their first entry to work. Additionally, inspectors' conflict of interest declarations must be taken by the Agency and renewed periodically.

\section{CONCLUSION}

The drugs patent protection regime brought to drugs with the TRIPS Agreement is encouraging the pharmaceutical industry at the point of original drug discovery. However, obstacles related to the protection of the right to health and access to essential medicines should not be overlooked. The problems of developing countries regarding access to essential medicines must be remedied. Governments must find the necessary solutions related to these issues, and essential medicines must always be accessible by the public. Governments and the pharmaceutical companies must fulfill the ethical obligations imposed on them. Pharmaceutical companies should perform R\&D for profitable diseases and orphan drugs, and they have to conduct studies for health problems in developing countries. In the clinical research processes of orphan drugs yet to receive regulatory approval, utmost importance should be given to ethical principles in the implementation supply to people with severe illnesses. At this point, moral principles such as informed consent, respect for autonomy, beneficence, and nonmaleficence are becoming crucial.

Regarding our national interests and pharmacoeconomic terms, choosing the cheapest between drugs with the same efficacy as a reference for pricing drugs is a logical and consistent action for our economic interests. If the RPS is applied, currency differences with the countries concerned should be arranged taking available national resources and pharmacoeconomic considerations into account. There must be no problem regarding the supply of essential drugs of foreign origin. Essential medicines should always be accessible in our country.

The Turkish drug industry should be supported, and more resources should be transferred to $R \& D$ activities. $R \& D$ activities must be conducted regarding biologic medicines, biosimilar products, and biotechnology products, which are of increasing importance in the world. The supply of surplus drugs should be rearranged to provide a common ground for the pharmaceutical industry, pharmaceutical warehouses, and pharmacies. As a result of pharmacoeconomic evaluations, if there is a generic equivalent drug having a lower price, it must be chosen and provided to the patient.

In the Turkish pharmaceutical industry, promotions should not only be for profit purposes and should not be conducted by non-qualified people. Drug promotions should be made based on scientific evidence and in an ethical manner by qualified product promotion members who have received a qualification certificate.

Inspections of the pharmaceutical industry must be performed by inspectors who are extremely well informed regarding all aspects of drug manufacturing through to delivering products to patients. Thus, various problems may be fixed during the manufacturing processes. Also, inspectors must comply with ethical principles during inspections. It is crucial to carefully follow whether deficiencies have been fixed owing to the fundamental requirement that drugs must always be top-grade quality.

Conflict of Interest: No conflict of interest was declared by the author.

\section{REFERENCES}

1. Sykes AO. TRIPs, Pharmaceuticals, Developing Countries, and the Doha “Solution, John M. Olin Program in Law and Economics Working Paper No 140, 2012.

2. T'Hoen EFH, TRIPS, Pharmaceutical Patents and Access to Essential Medicines: Seattle, Doha and Beyond. In: Economics Of Aids And Access To Hiv/Aids Care In Developing Countries Issues And Challenges, Ed(s): J.P. Moatti, B. Coriat, Y. Souteyrand, T. Barnett, J. Dumoulin, Y.A. Flori, pp. 39-69, Anrs Collection Sciences Sociales Et Sida, Paris, 2013. 
3. Yalçıner UG. Illaç ve Patent Türkiye'de ve Dünyada Son Gelişmeler. Ankara Barosu Fikri Mülkiyet ve Rekabet Hukuku Dergisi. 2002:2.

4. United Nations Human Rights Office of the High Commissioner. Your Human Rights. http://www.ohchr.org/EN/Issues/Pages/ WhatareHumanRights.aspx (last visited: 05.02.2017).

5. United Nations. Universal Declaration of Human Rights. http:// www.un.org/en/universal-declaration-human-rights/ (last visited: 05.02.2017).

6. World Intellectual Property Organization (WIPO). What is Intellectual Property? WIPO Publication No: 450 (E). http://www.wipo.int/ edocs/pubdocs/en/intproperty/450/wipo_pub_450.pdf (last visited: 05.02.2017).

7. Charter of Fundamental Rights of the European Union. Official Journal of the European Communities 2000/C 364/01. http://www.europarl.europa. eu/charter/pdf/text_en.pdf (last visited: 05.02.2017).

8. International Covenant on Economic, Social and Cultural Rights. United Nations Office of the High Commissioner for Human Rights 1976; in accordance with article 27.

9. Convention on the Rights of the Child. United Nations Office of the High Commissioner for Human Rights 1990; in accordance with article 49.

10. Convention on the Elimination of All Forms of Discrimination Against Women. United Nations Office of the High Commissioner for Human Rights 1981; in accordance with article 27.

11. General Comment No. 14: The Right to the Highest Attainable Standard of Health (Art. 12). United Nations Office of the High Commissioner for Human Rights 2000; E/C. 12/2000/4.

12. Laing R, Waning B, Gray A, Ford N, 't Hoen E. 25 years of the WHO essential medicines lists: progress and challenges. Lancet. 2003;361:1723-1729.

13. Chapman RA. Approaching Intellectual Property as a Human Right: Obligations related to Article 15(I) (c). Copyright Bulletin Unesco Publishing XXXV (3), 4-36, 2001.

14. Büyüktanır BGÖ, Birinci G, Ömürgönülşen U. Trips Agreement and Ethical Responsibilities of Pharmaceutical Companies Concerning the Right to Health. Hacettepe University Journal of Faculty of Economics and Administrative Sciences. 2012;30:1-26.

15. Yücekal Y. Protection of Intellectual Property Rights at the International Level World Intellectual Property Organization (WIPO). Republic of Turkey Ministry of Foreign Affairs Journal of International Economic Issues VIII, 2003.

16. Koçkaya G, Wertheımer A, Kılıç P, Tanyeri P, Vural IM, Akbulat A, Artiran G, Kerman S. An Overview of the Orphan Medicines Market in Turkey. Value In Health Reg Issues. 2004;4C:47-52.
17. Gülpınar G, Uzun MB, Yalım NY. The effects of Social Security Institution implementations on community pharmacists' job satisfaction: a qualitative study. Turkish Journal of Bioethics. 2015;2:36-46.

18. 6769 sayılı Sınai Mülkiyet Kanunu. Türkiye Cumhuriyeti mevzuatı. Türkiye Cumhuriyeti Resmi Gazete 10.01.2017; 29944. (No. 6769 Industrial Property Law. Legislation of the Republic of Turkey. The Official Gazette of Republic of Turkey 10.01.2017; 29944).

19. Bird RC. Developing nations and the compulsory license: maximizing access to essential medicines while minimizing investment side effects. J Law Med Ethics. 2009;37:209-221.

20. Beşeri Tıbbi Ürünler Ruhsatlandırma Yönetmeliği. Türkiye Cumhuriyeti mevzuatı. Türkiye Cumhuriyeti Resmi Gazete 19.01.2005; 25705. (Licensing Regulation of Human Medicinal Products. Legislation of the Republic of Turkey. The Official Gazette of Republic of Turkey 19.01.2005; 25705).

21. Illbars H, Irmak DK, Akan H. Orphan Drugs: R\&D Challenges with Updates from Turkey and Middle East Countries. Journal for Clinical Studies. 2014;6:58-63.

22. Kılıç P, Koçkaya G, Yemșen Ö, Tan C, Öztunca FH, Aksungur P. Kerman S. Orphan drug regulations in Turkey. J Pharm Health Serv Res. 2013;4:151153.

23. Beşeri Tıbbi Ürünlerin Fiyatlandırılması Hakkında Tebliğ. Türkiye Cumhuriyeti mevzuatı. Türkiye Cumhuriyeti Resmi Gazete 11.12.2015; 29559. (Communique on the Pricing of Human Medicinal Products. Legislation of the Republic of Turkey. The Official Gazette of Republic of Turkey 11.12.2015; 29559).

24. Çakı AU. Eczane İșletmelerinde Muhasebe ve Vergi Uygulamaları. Türk Eczacılar Birliği Meslek İçi Sürekli Eğitim Dergisi 21-22, 85-102, 2009.

25. Beşeri Tıbbi Ürünlerin Tanıım Faaliyetleri Hakkında Yönetmelik. Türkiye Cumhuriyeti mevzuatı. Türkiye Cumhuriyeti Resmi Gazete 03.07.2015; 29405. (Regulation on Promotional Activities of the Human Medicinal Products. Legislation of the Republic of Turkey. The Official Gazette of Republic of Turkey 03.07.2015; 29405).

26. Beşeri Tıbbi Ürünler İmalathaneleri Yönetmeliği. Türkiye Cumhuriyeti mevzuatı. Türkiye Cumhuriyeti Resmi Gazete 27.04.2013; 28630. (Regulation on Manufacturing of the Human Medicinal Products. Legislation of the Republic of Turkey. The Official Gazette of Republic of Turkey 27.04.2013; 28630).

27. Türkiye Illaç ve Tıbbi Cihaz Kurumu Sağlık Denetçileri Yönetmeliği. Türkiye Cumhuriyeti mevzuatı. Türkiye Cumhuriyeti Resmi Gazete 30.05.2013; 28662. (Turkish Medicines and Medical Devices Agency Regulation of Health Inspectors. Legislation of the Republic of Turkey. The Official Gazette of Republic of Turkey 30.05.2013; 28662). 